\title{
The assessment of psychopathological symptoms and the course of schizophrenia depending on gender, duration of the disease, somatic comorbidity and suicide attempts
}

\author{
Ocena objawów psychopatologicznych oraz przebiegu schizofrenii w zależności od \\ płci, czasu trwania choroby, wspótchorobowości somatycznej oraz prób samobójczych
}

Marta Broniarczyk-Czarniak ${ }^{1}$, Agata Orzechowska ${ }^{1}$, Piotr Gałecki ${ }^{1}$

\section{ABSTRACT}

Objectives. Schizophrenia is a chronic mental disorder with periods of exacerbation and remission. The prevalence during life is estimated at $0.5-1 \%$. The study aims to prove that there are differences in the prevalence of positive and negative symptoms of schizophrenia depending on the gender and duration of the disease, and

\footnotetext{
Received: $\quad 8.06 .2020$ Accepted: $\quad 7.07 .2020$

AFFiliation / AFILIACJA

Department of Adult Psychiatry, Medical University of Lodz

\section{KEYWORDS}

- schizophrenia

- positive symptoms

- negative symptoms

- comorbid illness

CORRESPONDENCE ADDRESS / ADRES DO KORESPONDENCJI

Marta Broniarczyk-Czarniak

Medical University of Lodz

Department of Adult Psychiatry

ul. Aleksandrowska 159, 91-229 Lodz, Poland

email: martabroniarczyk@op.pl

SŁOWA KLUCZOWE

- schizofrenia

- choroby współistniejące

- objawy negatywne

- objawy pozytywne
}

to confirm that there is a relationship between the factors such as the occurrence of somatic diseases and the risk of suicide attempts, and a specific clinical picture and course of the disease.

Material and methods. The study included 76 patients with schizophrenia treated with standard antipsychotic pharmacotherapy. The severity of psychopathological symptoms was assessed after admission to hospital using the scale of positive and negative symptoms and the sociodemographic survey created for the purposes of this study.

Results. The first episode of schizophrenia in men occurs earlier than in women. There are no statistically significant differences in the psychopathological picture of the disease in men and women. The severity of negative symptoms increases with the duration of the illness for the entire population of the study. Patients with schizophrenia without co-occurring somatic diseases have more severe positive symptoms of illness. There are no statistically significant differences in the group of patients who attempted suicide and who did not.

Conclusions. Positive symptoms of the disease are more common in younger patients without somatic diseases while negative symptoms increase with age. Men develop first symptoms of schizophrenia earlier than women. It is not possible to distinguish the dominant group of psychopathological symptoms for women and men in patients who suffer somatic diseases and attempt suicide more often. 


\section{STRESZCZENIE}

Cel pracy. Schizofrenia to przewlekła choroba psychiczna, przebiegająca z okresami zaostrzeń i remisji. Rozpowszechnienie choroby w ciągu życia szacuje się na $0,5-1 \%$. Celem badania była próba dowiedzenia, że istnieją różnice w rozpowszechnieniu objawów pozytywnych i negatywnych schizofrenii w zależności od płci i czasu trwania choroby, oraz potwierdzenie, że istnieje związek pomiędzy występowaniem chorób somatycznych oraz ryzykiem podejmowania prób samobójczych a określonym obrazem klinicznym i przebiegiem choroby.

Materiał i metody. Do badania włączono 76 pacjentów $\mathrm{z}$ rozpoznaniem schizofrenii leczonych standardową farmakoterapią przeciwpsychotyczną. Nasilenie objawów psychopatologicznych oceniano po przyjęciu do szpitala za pomocą skali objawów pozytywnych i negatywnych (PANSS) oraz ankiety socjodemograficznej stworzonej na potrzeby tego badania.

\section{Introduction}

Schizophrenia is a chronic mental disorder with periods of exacerbation and remission. Its prevalence during life is estimated at 0.5-1\% (Saha et al., 2005; Lora et al., 2012; Charlson et al., 2018). Schizophrenia occurs equally often in men and women, but the course of the disease varies greatly depending on the gender (Saha et al., 2005; Charlson et al., 2018). The differences, confirmed in many scientific studies, include the earlier onset of the disease in men (McGrath et al., 2004; Galderisi et al., 2012; Sun et al., 2016; Gogos et al., 2019), which is usually at least a few years ahead of the onset of the disease in women, as well as the greater propensity to addiction and generally worse long-term prognosis in men (Koster et al., 2008; Zhang et al., 2012). Studies on the differences in the psychopathological picture are not fully consistent, which raises the need for further research. Some researchers indicate a higher prevalence of positive and affective symptoms in women, which may result in better prognosis (Zhang et al., 2012). Others show no significant differences in the range of positive and negative symptoms depending on the gender (Szymanski et al., 1995; Ochoa et al., 2012). The prognosis regarding full remission of symptoms is unfavourable while clinical and social criteria of full remission of the disease are met by only $13.5 \%$ of patients (Jaaskelainen et al., 2013; Charlson et al., 2018). Mortality rates in patients with schizophrenia are higher than in the general population due to higher suicide rates and somatic comorbidity (Auquier et al., 2006). It is estimated that up to $50 \%$ of schizophrenic patients have suicidal thoughts and $10 \%$
Wyniki. Pierwszy epizod schizofrenii u mężczyzn pojawia się wcześniej niż u kobiet. Nie wykazano istotnych statystycznie różnic w obrazie psychopatologicznym choroby w zależności od płci. Wraz z czasem trwania choroby obserwowano nasilenie występowania objawów negatywnych w całej badanej populacji. Pacjenci ze schizofrenią, u których nie występowały schorzenia współistniejące, mieli bardziej nasilone objawy pozytywne choroby. Nie wykazano istotnych statystycznie różnic w podgrupach pacjentów podejmujących próby samobójcze oraz pacjentów niepodejmujących takich prób.

Wnioski. Objawy pozytywne choroby występują częściej w grupie pacjentów młodszych, bez współistniejących chorób somatycznych, natomiast wraz z wiekiem pacjenta narastają trudne do leczenia objawy negatywne. Mężczyźni zaczynają chorować na schizofrenię wcześniej. Nie można wyróżnić dominującej grupy objawów psychopatologicznych u kobiet i mężczyzn, u pacjentów z chorobami somatycznymi oraz podejmujących częściej próby samobójcze.

of them die of suicide (Meltzer et al., 2003; Pompili et al., 2007; Simms et al., 2007). The main somatic diseases among these patients include diabetes and cardiovascular diseases (Crump et al., 2013).

The aim of the study was to prove that there are differences in the prevalence of positive and negative symptoms of schizophrenia depending on the gender and duration of the disease, and to confirm that there is a relationship between the factors such as the occurrence of somatic diseases and the risk of suicide attempts, and a specific clinical picture and course of the disease.

\section{Methods}

\section{Study participants}

The study was conducted among patients hospitalised 24 hours a day in the Specialist Psychiatric Health Care Centre in Łódź. The study included 76 patients with the diagnosis of schizophrenia, based on diagnostic criteria included in the International Statistical Classification of Diseases and Health Problems (ICD-10). Patients were divided into subgroups by gender, co-occurrence of somatic diseases, suicide attempts and duration of the disease. The first group consisted of 40 patients with a period of 10 to 15 years after the diagnosis while the second group consisted of 36 patients with the first episode of schizophrenia or treatment period not longer than 2 years. Patients were treated with standard antipsychotic pharmacotherapy. All patients gave informed written consent to participate in the study. The study 
received a positive opinion of the Bioethics Committee of the Medical University of Łódź.

To obtain basic sociodemographic data, the sociodemographic survey, created for the purposes of the study, was conducted. Additionally, the extended survey was performed to obtain the following information: age of onset of the first episode, duration of the treatment, number of psychiatric hospitalisations, occurrence and type of somatic diseases as well as number and type of suicide attempts. The severity of psychopathological symptoms was assessed after admission to hospital using the Positive and Negative Syndrome Scale (PANSS) (Kay et al., 1987). Based on the structured clinical history, the severity of individual symptoms was rated on a scale from 1 (none) to 7 (maximum symptom severity).

\section{Statistical analysis}

The statistical analysis of the results was performed using the STATISTICA 13.3 PL. In the statistical verification of hypotheses, a two-sided critical area was assumed. In order to select the type of measurement, the variables used in the study were analysed. The analysis showed that the hypothesis regarding compliance with normal distribution should be rejected. In order to demonstrate the statistical significance of the relationship between the variables among patients treated for schizophrenia, the statistical analysis based on non-parametric tests was performed, also in relation to the size of the group. The Mann-Whitney U-test and R-Spearman's rank correlation were applied. For all statistical methods used, the assumed level of significance was $p<0.05$.

\section{Results}

The experimental group covered a total of 76 people, including 40 women and 36 men (Table 1). The average PANSS score was 117.61 points $(S D=18.56)$. Other average scores were as follows: 28.61 points $(S D=10.60)$ on the scale of positive symptoms for the whole population, 26.70 points $(\mathrm{SD}=9.23$ ) on the scale of negative symptoms and 62.30 points $(S D=9.29)$ on the scale of general symptoms. Average scores obtained in the scales did not vary depending on the duration of the disease in both groups. Spearman correlation for the whole study group showed a statistically significant age correlation with the scores obtained in the PANSS negative scale $(R=0.26, p=0.025)$. This means that the higher the age of patients, the higher the scores obtained on the scale of negative symptoms.

\section{Scores for the population divided by gender}

In the study population, women and men differed statistically significantly in terms of age $(Z=3.47 ; p=0.001)$ and age of onset of the first episode $(Z=3.85 ; p=0.000)$. The average age was 40.73 years $(S D=12.22)$ for women and 31.19 years $(S D=9.59)$ for men. The age of onset of the first episode in the entire study population was earlier in men, averaging 24.94 years $(S D=8.59)$ for men and 32.55 years $(\mathrm{SD}=11.47)$ for women. With the duration of the disease included, these differences were statistically significant in each group (Tables 2 and 3 ). The scores obtained in the PANSS scale did not differ significantly depending on the gender of the study participants.

Table 1. Characteristics of the study group

\begin{tabular}{|llll}
\hline Data & $\begin{array}{l}\text { Sample group } \\
\text { Entire } \\
\text { population }\end{array}$ & $\begin{array}{l}\text { Long-term } \\
\text { schizophrenia } \\
(\mathbf{1 0 - 1 5} \text { years) }\end{array}$ & $\begin{array}{l}\text { Schizophrenia } \\
\text { up to 2 years }\end{array}$ \\
Gender & $40 \mathrm{~F}, 36 \mathrm{M}$ & $24 \mathrm{~F}, 16 \mathrm{M}$ & $16 \mathrm{~F}, 20 \mathrm{M}$ \\
Age & $\begin{array}{l}36.21 \pm 11.98 \\
(\min .18 /\end{array}$ & $\begin{array}{l}40.60 \pm 8.37 \\
(\min .26 /\end{array}$ & $\begin{array}{l}31.33 \pm 13.53 \\
(\min .18 /\end{array}$ \\
& $\max .74)$ & $\max .64)$ & $\max$ 74)
\end{tabular}

Table 2. Differences between women (16) and men (20), schizophrenia - treatment up to 2 years

\begin{tabular}{|lllll}
\hline & $Z$ & $p$ & Women & Men \\
\hline Positive Scale & -0.764 & 0.445 & 16 & 20 \\
Negative Scale & 0.684 & 0.494 & 16 & 20 \\
General Scale & -0.191 & 0.849 & 16 & 20 \\
PANNS & -0.334 & 0.738 & 16 & 20 \\
Age & 2.372 & 0.018 & 16 & 20 \\
First episode (age) & 2.356 & 0.018 & 16 & 20 \\
$\begin{array}{l}\text { Duration of treatment } \\
\text { (years) }\end{array}$ & 0.175 & 0.861 & 16 & 20 \\
$\begin{array}{l}\text { Number of suicide } \\
\text { attempts }\end{array}$ & -0.107 & 0.915 & 4 & 6 \\
Number of hospitalisations & -0.414 & 0.679 & 16 & 20 \\
\hline
\end{tabular}

Table 3. Differences between women (24) and men (16), schizophrenia - treatment between 10-15 years

\begin{tabular}{|lllll}
\hline \multicolumn{1}{|l}{$Z$} & $Z$ & $p$ & Women & Men \\
\hline Positive Scale & -0.66 & 0.508 & 24 & 16 \\
Negative Scale & -0.58 & 0.562 & 24 & 16 \\
General Scale & -0.07 & 0.945 & 24 & 16 \\
PANNS & -0.41 & 0.679 & 24 & 16 \\
Age & 3.35 & 0.001 & 24 & 16 \\
First episode (age) & 3.33 & 0.001 & 24 & 16 \\
$\begin{array}{l}\text { Duration of treatment } \\
\text { (years) }\end{array}$ & 0.91 & 0.362 & 24 & 16 \\
Number of attempts, type & 0.50 & 0.617 & 6 & 7 \\
Number of hospitalisations & -1.20 & 0.230 & 24 & 16
\end{tabular}

\section{Scores for the study population divided by occurrence of suicide attempts}

Out of the entire study population, 23 people attempted suicide and 53 did not. There was no statistically significant difference between the number of suicide attempts 
in the group of women and men. Among those who attempted suicide and who did not, there were no statistically significant differences in the duration of the disease, the type of prevailing psychopathological symptoms and the course of the treatment.

\section{Scores for the study population divided by occurrence of somatic diseases}

In the entire study population, 49 people were not diagnosed with any somatic disease and 27 people were treated for coexisting somatic diseases. The subgroups differed statistically significantly by severity of positive symptoms of the disease, age, age of onset of the first episode, duration of the treatment and number of psychiatric hospitalisations (Table 4). Patients who were not treated for somatic diseases were younger and had started to fall ill earlier. Their average age was 32.71 years (SD $=10.96)$ compared to 42.56 years $(\mathrm{SD}=11.29)$ in patients with somatic diseases. The age of onset of the first episode was on average 26.78 years $(S D=10.19)$ in patients without somatic disease and 32.89 years $(S D=11.06)$ in patients with somatic burden. There was a longer average duration of the treatment and a higher number of psychiatric hospitalisations in patients with somatic diseases, i.e. 9.67 years $(\mathrm{SD}=4.92)$ and 6.19 hospitalisations $(\mathrm{SD}$ $=4.80)$ respectively, compared to 5.94 years $(\mathrm{SD}=5.38)$ and 3.96 hospitalizations $(S D=3.51)$. Patients who were not diagnosed with coexisting diseases had a statistically significantly higher score on the PANSS positive scale, i.e. on average 31.31 points $(\mathrm{SD}=10.37)$ compared to 23.70 points $(\mathrm{SD}=9.31)$ in patients with coexisting somatic diseases. The Spearman correlation in patients without somatic disease showed a statistically significant correlation of age $(R=0.42 ; p=0.003)$ and age of onset of the first episode $(R=0.51 ; p=0.000)$ with the PANSS general symptom scale as well as a statistically significant correlation of age $(R=0.35 ; p=0.013)$ and age of onset of the first episode $(R=0.37 ; p=0.008)$ with the total score in the PANSS scale.

Table 4. Differences between groups in terms of somatic comorbidity

\begin{tabular}{|c|c|c|c|c|}
\hline & \multirow[t]{2}{*}{$\bar{Z}$} & \multirow[t]{2}{*}{$\bar{p}$} & \multicolumn{2}{|c|}{ Somatic illness $(n)$} \\
\hline & & & $\begin{array}{l}\text { does not } \\
\text { occur }\end{array}$ & occurs \\
\hline Positive Scale & 3.11 & 0.002 & 49 & 27 \\
\hline Negative Scale & -1.63 & 0.102 & 49 & 27 \\
\hline General Scale & 1.00 & 0.318 & 49 & 27 \\
\hline PANNS & 1.30 & 0.195 & 49 & 27 \\
\hline First episode (age) & -2.98 & 0.003 & 49 & 27 \\
\hline $\begin{array}{l}\text { Duration of treatment } \\
\text { (years) }\end{array}$ & -2.82 & 0.005 & 49 & 27 \\
\hline Number of hospitalisations & -2.43 & 0.015 & 49 & 27 \\
\hline Age & -3.64 & 0.000 & 49 & 27 \\
\hline
\end{tabular}

\section{Discussion}

Schizophrenia is a disease that can vary depending on the gender. The results obtained in the study prove that the symptoms of the disease appear earlier in men than in women. In men, the first episode appeared over 7 years earlier. These results are consistent with studies conducted so far, according to which the age of onset of the first episode was usually between 18 and 25 years in men and between 25 and 35 years in women, with a second peak in the perimenopausal period (McGrath et al., 2004; Galderisi et al., 2012; Sun et al., 2016; Gogos et al., 2019). The study did not show the predominance of any of the symptom groups depending on the gender.

The subsequent results show that negative symptoms begin to prevail in the psychopathological picture with the duration of the disease. This group of symptoms includes primarily social withdrawal, lack of motivation, apathy, abulia and lack of spontaneity (Kahn et al., 2015). Negative symptoms may be primary, i.e. resulting from the disease process itself, or secondary, i.e. arising from the antipsychotic treatment, co-occurring depression, social deprivation or abuse of psychoactive substances (Kirschner et al., 2017). With their occurrence, there is a tendency for symptoms to persist and drug resistance occurs more frequently. In patients with prevailing negative symptoms, atypical antipsychotics are used as the first-line drugs (Szulc et al., 2019). However, their effectiveness is still lower than expected. The impact of negative symptoms implies worse functional improvement of patients' mental state and has a significant influence on their life in society.

The results of the study also indicate a predominance of positive symptoms in patients without somatic diseases. Patients in this group were younger and were treated for a shorter period. However, it seems that this analysis has to be treated with cautiousness despite its statistical significance. It is a well-known fact that patients without somatic diseases are younger and exhibit positive symptoms of the disease more frequently. The prevalence of positive symptoms may be a favourable prognosis factor. Positive symptoms are susceptible to antipsychotic treatment. Both first and second generation antipsychotics prove effective in this case (Leucht et al., 2009).

The increase, with age, in the number of points scored on the PANSS general symptom scale in patients without somatic diseases is an interesting finding which certainly requires further research. The PANSS general symptoms scale covers 16 symptoms rated on a 7-point scale. The symptoms may be indirectly related to both negative and positive symptoms of the disease. For correct conclusions, further research should focus on determining the prevailing symptoms in this group of patients. One of the symptoms included in the PANSS general symptoms scale is care for physical health. In 
a sense, greater care for physical health can be a beneficial symptom leading to a better physical condition and thus reducing the risk of somatic diseases. On the other hand, given that the assessment of patients' mental condition took place shortly after admission to hospital, non-characteristic symptoms, such as irritability, tension, anxiety and depression, present in the PANSS general symptoms scale, may coexist in patients with various somatic diseases. Moreover, active avoidance of social contacts and exacerbation of negative symptoms, also with age, may lead to insufficient diagnosis, prognosis and treatment of coexisting diseases in this group of patients.

The risk of somatic diseases that schizophrenia poses is higher than in the general population and life expectancy is shorter by up to 20 years (Saha et al., 2005; Saha et al., 2007; Jaaskelainen et al., 2013; Chesney et al., 2014). Cardiovascular diseases, including ischemic heart disease and type II diabetes, strokes and respiratory diseases are the most common somatic diseases (Charlson et al., 2018). The meta-analysis of research on the causes of death in patients with schizophrenia, conducted by Piotrowski et al., clearly indicates that patients with schizophrenia are insufficiently diagnosed and treated for somatic diseases. Moreover, while the general population exhibits an increasing life expectancy as a result of the development of medicine and greater availability of health care, life expectancy of patients with schizophrenia does not change, or becomes even shorter as evidenced in the studies (Piotrowski et al., 2017).

Higher mortality rates are not only due to somatic diseases, but also suicides. Up to $10 \%$ of schizophrenic patients die of suicide (Meltzer et al., 2003; Pompili et al., 2007; Simms et al., 2007). It is necessary to identify the risk factors for committing a suicidal act and to implement measures to minimise the risk. The results of the study do not indicate significant correlations between any of the variables and the increased risk of suicide.

\section{Conclusions}

Positive symptoms of the disease are more frequent in the group of younger patients, without coexisting somatic diseases, while negative symptoms, difficult to treat, appear with age. Men develop schizophrenia earlier than women. It is not possible to indicate the prevailing psychopathological symptoms for women and men in patients with somatic diseases and those who attempt suicide more often.

\section{Test limitations}

The limitations which undoubtedly should be taken into account in the analysis of the results of the study include relatively small groups of patients.

\section{Wstęp}

Schizofrenia to przewlekła choroba psychiczna, przebiegająca z okresami zaostrzeń i remisji. Rozpowszechnienie choroby w ciągu życia szacuje się na 0,5-1\% (Saha i wsp., 2005; Lora i wsp., 2012; Charlson i wsp., 2018). Schizofrenia występuje równie często u mężczyzn, jak i u kobiet, ale przebieg schorzenia różni się znacznie w zależności od płci (Saha i wsp., 2005; Charlson i wsp., 2018). Można wymienić tutaj potwierdzone w wielu badaniach naukowych różnice dotyczące wcześniejszego początku choroby u mężczyzn (McGrath i wsp., 2004; Galderisi i wsp., 2012; Sun i wsp., 2016; Gogos i wsp., 2019), wyprzedzającego zwykle o co najmniej kilka lat początek choroby u kobiet, większą skłonność do uzależnień oraz generalnie gorsze długoterminowe rokowanie u mężczyzn (Koster i wsp., 2008; Zhang i wsp., 2012). Badania dotyczące różnic w obrazie psychopatologicznym nie są w pełni zgodne, co skłania do prowadzenia dalszych badań w tym kierunku. Część badaczy wskazuje na większe rozpowszechnienie objawów pozytywnych i afektywnych u kobiet, co może wiązać się z lepszym rokowaniem (Zhang i wsp., 2012). Pozostali nie wykazują

istotnych różnic w zakresie objawów pozytywnych i negatywnych w zależności od płci (Szymanski i wsp., 1995; Ochoa i wsp., 2012). Rokowanie dotyczące pełnej remisji objawów jest niekorzystne, a kliniczne oraz społeczne kryteria pełnej remisji choroby spełnia tylko $13,5 \%$ pacjentów (Jaaskelainen i wsp., 2013; Charlson i wsp., 2018). Wskaźniki śmiertelności u pacjentów ze schizofrenią są wyższe niż w populacji ogólnej, co ma związek z wyższym wskaźnikiem samobójstw oraz współchorobowością somatyczną (Auquier i wsp., 2006). Szacuje się, że nawet $50 \%$ pacjentów ze schizofrenią ma myśli samobójcze, a 10\% z nich umiera z powodu dokonanego samobójstwa (Meltzer i wsp., 2003; Pompili i wsp., 2007; Simms i wsp., 2007). Wśród schorzeń somatycznych wśród tych chorych dominuje cukrzyca i choroby układu krążenia (Crump i wsp., 2013).

Celem tego badania była próba dowiedzenia, że istnieją różnice w rozpowszechnieniu objawów pozytywnych i negatywnych schizofrenii w zależności od płci i czasu trwania choroby, oraz potwierdzenie, że zachodzi związek pomiędzy występowaniem chorób somatycznych oraz ryzykiem podejmowania prób samobójczych a określonym obrazem klinicznym i przebiegiem choroby. 


\section{Metody}

\section{Osoby badane}

Badanie zostało przeprowadzone wśród pacjentów hospitalizowanych całodobowo w Specjalistycznym Psychiatrycznym Zespole Opieki Zdrowotnej w Łodzi. Do badania włączono 76 pacjentów z rozpoznaniem schizofrenii, postawionym na podstawie kryteriów diagnostycznych zawartych w Międzynarodowej Statystycznej Klasyfikacji Chorób i Problemów Zdrowotnych (ICD-10, International Classification of Diseases). Pacjentów podzielono na podgrupy ze względu na płeć, współwystępowanie chorób somatycznych, podejmowanie prób samobójczych oraz czas trwania choroby. Pierwszą grupę stanowiło 40 pacjentów w okresie od 10 do 15 lat od postawienia rozpoznania, a drugą 36 pacjentów z pierwszym epizodem schizofrenii lub okresem leczenia nie dłuższym niż 2 lata. Pacjenci leczeni byli standardową farmakoterapią przeciwpsychotyczną. Wszyscy pacjenci wyrazili świadomą, pisemną zgodę na udział w badaniu. Badanie uzyskało pozytywną opinię Komisji Bioetycznej Uniwersytetu Medycznego w Łodzi.

Wśród pacjentów przeprowadzono stworzoną na potrzeby badania ankietę pozwalającą uzyskać podstawowe dane socjodemograficzne. Dodatkowo w formie rozszerzonej ankiety zebrano informacje dotyczące wieku pojawienia się pierwszego epizodu psychotycznego, czasu trwania leczenia, liczby hospitalizacji psychiatrycznych, występowania i rodzaju chorób somatycznych oraz podejmowania przez badanych prób samobójczych, ich liczby i rodzaju. Nasilenie objawów psychopatologicznych oceniano po przyjęciu do szpitala za pomocą skali objawów pozytywnych i negatywnych (PANSS, Positive and Negative Syndrom Scale) (Kay i wsp., 1987). Posługując się ustrukturyzowanym wywiadem klinicznym, oceniono nasilenie poszczególnych objawów w skali od 1 (brak) do 7 (maksymalne nasilenie objawu).

\section{Analiza statystyczna}

Do analizy statystycznej otrzymanych wyników wykorzystano program statystyczny STATISTICA 13.3 PL. Podczas statystycznej weryfikacji hipotez przyjęto dwustronny obszar krytyczny. W celu wyboru rodzaju pomiaru przeprowadzono analizę badanych zmiennych, która wykazała, że hipotezę o zgodności z rozkładem normalnym należy odrzucić. W celu wykazania istotności statystycznej związku analizowanych zmiennych wśród pacjentów leczonych z powodu schizofrenii wykonano analizę statystyczną w oparciu o testy nieparametryczne, również w związku z liczebnością grupy. Zastosowano test różnic U Manna-Whitneya, a także korelację rang R-Spearmana. We wszystkich użytych metodach statystycznych za poziom istotności przyjęto wartość: $p<0,05$.

\section{Wyniki}

W grupie eksperymentalnej znajdowało się łącznie 76 osób, w tym 40 kobiet i 36 mężczyzn (tabela 1). Badani pacjenci uzyskali średni wynik w skali PANSS wynoszący 117,61 punktów $(S D=18,56)$. Średni wynik w skali objawów pozytywnych dla całej badanej populacji wyniósł 28,61 punktów $(S D=10,60)$, w skali objawów negatywnych 26,70 punktów $(S D=9,23)$, a w skali objawów ogólnych 62,30 punktów $(S D=9,29)$. Średnie wyniki uzyskane w tych skalach nie różniły się w zależności od czasu trwania choroby w obu grupach. Korelacja Spearmana dla całej badanej grupy wykazała istotną statystycznie korelację wieku z wynikami uzyskanymi w skali negatywnej PANSS $(R=0,26, p=0,025)$. Oznacza to, że im wyższy był wiek pacjentów, tym wyższe wyniki uzyskiwali w skali objawów negatywnych.

Tabela 1. Charakterystyka badanej grupy

\begin{tabular}{|llll}
\hline Dane & $\begin{array}{l}\text { Grupa badana } \\
\text { cała populacja }\end{array}$ & $\begin{array}{l}\text { Schizofrenia } \\
\text { wieloletnia } \\
\text { (10-15 lat) }\end{array}$ & $\begin{array}{l}\text { Schizofrenia } \\
\text { do 2 lat }\end{array}$ \\
Płeć & $40 \mathrm{~K}, 36 \mathrm{M}$ & $24 \mathrm{~K}, 16 \mathrm{M}$ & $16 \mathrm{~K}, 20 \mathrm{M}$ \\
Wiek & $\begin{array}{l}36,21 \pm 11,98 \\
(\min .18 /\end{array}$ & $\begin{array}{l}40,60 \pm 8,37 \\
\text { (min. 26 / }\end{array}$ & $\begin{array}{l}31,33 \pm 13,53 \\
\text { (min. 18 / }\end{array}$ \\
& maks. 74) & maks. 64) & maks. 74)
\end{tabular}

\section{Wyniki dla badanej populacji podzielonej ze względu na płeć}

Kobiety i mężczyźni w badanej populacji różnili się między sobą w sposób istotny statystycznie pod względem wieku $(Z=3,47 ; p=0,001)$ oraz wieku wystąpienia pierwszego epizodu choroby $(Z=3,85 ; p=0,000)$. Średni wiek kobiet uczestniczących w badaniu wynosił 40,73 roku $(\mathrm{SD}=12,22)$, a mężczyzn 31,19 roku $(\mathrm{SD}=9,59)$. Wiek pojawienia się pierwszego epizodu choroby w całej badanej populacji był wcześniejszy u mężczyzn $i$ wynosił średnio 24,94 lata $(S D=8,59)$, a u kobiet 32,55 lat $(S D=11,47)$. Różnice te były istotne statystycznie również w każdej z grup, gdy uwzględniono czas trwania choroby (tabela 2 i 3). Wyniki uzyskane w skali PANSS nie różniły się istotnie w zależności od płci uczestników badania.

Tabela 2. Różnice między kobietami (16) a mężczyznami (20), schizofrenia - leczenie do 2 lat

\begin{tabular}{|lllll}
\hline & $Z$ & $p$ & Kobiety & Mężczyźni \\
Positive Scale & $-0,764$ & 0,445 & 16 & 20 \\
Negative Scale & 0,684 & 0,494 & 16 & 20 \\
General Scale & $-0,191$ & 0,849 & 16 & 20 \\
Skala PANNS & $-0,334$ & 0,738 & 16 & 20 \\
Wiek & 2,372 & 0,018 & 16 & 20 \\
$\begin{array}{l}\text { Pierwszy epizod choroby } \\
\text { (wiek) }\end{array}$ & 2,356 & 0,018 & 16 & 20 \\
Czas trwania leczenia (lata) & 0,175 & 0,861 & 16 & 20 \\
Liczba prób samobójczych & $-0,107$ & 0,915 & 4 & 6 \\
Liczba hospitalizacji & $-0,414$ & 0,679 & 16 & 20
\end{tabular}


Tabela 3. Różnice między kobietami (24) a mężczyznami (16), schizofrenia - leczenie do 10-15 lat

\begin{tabular}{|lllll}
\hline & $Z$ & $p$ & Kobiety & Mężczyźni \\
Positive Scale & $-0,66$ & 0,508 & 24 & 16 \\
Negative Scale & $-0,58$ & 0,562 & 24 & 16 \\
General Scale & $-0,07$ & 0,945 & 24 & 16 \\
PANNS & $-0,41$ & 0,679 & 24 & 16 \\
Wiek & 3,35 & 0,001 & 24 & 16 \\
$\begin{array}{l}\text { Pierwszy epizod choroby } \\
\text { (wiek) }\end{array}$ & 3,33 & 0,001 & 24 & 16 \\
$\begin{array}{l}\text { Czas trwania leczenia (lata) } \\
\text { Liczba prób, rodzaj }\end{array}$ & 0,91 & 0,362 & 24 & 16 \\
Liczba hospitalizacji & 0,50 & 0,617 & 6 & 7 \\
\hline & $-1,20$ & 0,230 & 24 & 16
\end{tabular}

\section{Wyniki dla badanej populacji podzielonej ze względu na obecność prób samobójczych}

Spośród całej badanej populacji 23 osoby podjęły próbę samobójczą, a 53 nie podjęły próby. Nie wykazano istotnej statystycznie różnicy pomiędzy ilością podejmowanych prób samobójczych w grupie badanych kobiet i mężczyzn. Wśród osób, które podjęły próbę samobójczą i które jej nie podjęły, nie występowały istotne statystycznie różnice pod względem czasu trwania choroby, rodzaju dominujących objawów psychopatologicznych oraz przebiegu leczenia.

\section{Wyniki dla badanej populacji podzielonej ze względu na obecność chorób somatycznych}

W całej badanej populacji u 49 osób nie rozpoznano żadnej choroby somatycznej, a 27 osób było leczonych z powodu współistniejących chorób somatycznych. Badane podgrupy różniły się istotnie statystycznie ze względu na nasilenie objawów pozytywnych choroby, wiek pacjentów, wiek wystąpienia pierwszego epizodu choroby, czas trwania leczenia oraz liczbę hospitalizacji psychiatrycznych (tabela 4). Pacjenci nieleczeni z powodu chorób somatycznych byli młodsi oraz zaczynali chorować wcześniej. Ich średni wiek wynosił 32,71 roku $(S D=10,96)$ w porównaniu z 42,56 $(\mathrm{SD}=11,29)$ u pacjentów z chorobami somatycznymi. Wiek pierwszego epizodu choroby u pacjentów bez choroby somatycznej wynosił średnio 26,78 roku $(S D=10,19)$, a u pacjentów obciążonych dodatkowo somatycznie 32,89 roku $(S D=11,06)$. Średni czas trwania leczenia oraz liczba hospitalizacji psychiatrycznych były wyższe u pacjentów chorujących na schorzenia somatyczne i wynosiły odpowiednio 9,67 roku $(\mathrm{SD}=4,92)$ i 6,19 hospitalizacji $(S D=4,80)$ w porównaniu z 5,94 roku $(\mathrm{SD}=5,38)$ i 3,96 hospitalizacji $(\mathrm{SD}=3,51)$. Pacjenci bez rozpoznanych chorób współistniejących mieli statystycznie istotnie wyższy wynik uzyskany w skali pozytywnej PANSS, który wynosił średnio 31,31 punktów $(S D=10,37)$ w porównaniu z 23,70 punktów (SD = 9,31) u pacjentów ze współistniejącymi chorobami somatycznymi. Korelacja
Spearmana w grupie pacjentów bez choroby somatycznej wykazała istotną statystycznie korelację wieku $(R=0,42$; $p=0,003$ ) oraz wieku pierwszego epizodu schizofrenii $(R=0,51 ; p=0,000)$ ze skalą objawów ogólnych PANSS oraz wieku $(R=0,35 ; p=0,013)$ i wieku pierwszego epizodu schizofrenii $(R=0,37 ; p=0,008)$ z sumaryczną ilością punktów w skali PANSS.

Tabela 4. Różnice między grupami pod względem współchorobowości somatycznej

\begin{tabular}{|lllll}
\hline & $Z$ & $p$ & $\begin{array}{l}\text { Choroba } \\
\text { somatyczna }(n) \\
\text { nieobecna }\end{array}$ \\
obecna
\end{tabular}

$n$ - liczebność grupy

\section{Omówienie}

Schizofrenia to choroba, której przebieg może różnić się w zależności od płci osoby chorej. Wyniki uzyskane w tym badaniu dowodzą, że w grupie mężczyzn objawy choroby pojawiają się wcześniej niż u kobiet. Wiek wystąpienia pierwszego epizodu choroby u mężczyzn był o ponad 7 lat niższy. Wyniki te są zgodne z przeprowadzonymi do tej pory badaniami, wedle których wiek pierwszego epizodu choroby u mężczyzn przypadał zwykle między 18 a 25 rokiem życia, a u kobiet między 25 a 35 rokiem życia, z drugim szczytem zachorowań w okresie okołomenopauzalnym (McGrath i wsp., 2004; Galderisi i wsp., 2012; Sun i wsp., 2016; Gogos i wsp., 2019). W badaniu nie wykazano przewagi żadnej z grup objawów w zależności od płci badanego pacjenta.

Przywołując kolejne wyniki, możemy zauważyć, że wraz z czasem trwania choroby w obrazie psychopatologicznym zaczynają dominować objawy negatywne. Do tej grupy objawów zaliczamy przede wszystkim objawy społecznego wycofania, braku motywacji, apatii, abulii i braku spontaniczności (Kahn i wsp., 2015). Objawy negatywne mogą mieć charakter pierwotny - wynikający z samego procesu chorobowego - lub wtórny - związany ze stosowanym leczeniem przeciwpsychotycznym, współwystępującą depresją, deprywacją społeczną czy nadużywaniem substancji psychoaktywnych (Kirschner i wsp., 2017). Występowanie ich wiąże się z tendencją do przewlekania się objawów oraz częstszą lekoopornością. Lekami pierwszego rzutu w grupie pacjentów z dominującymi 
objawami negatywnymi są atypowe leki przeciwpsychotyczne (Szulc i wsp., 2019). Jednak ich skuteczność jest nadal niższa niż oczekiwana, a to właśnie wpływ objawów negatywnych implikuje gorszą funkcjonalną poprawę stanu psychicznego pacjentów oraz oddziałuje w sposób istotny na ich życie w społeczeństwie.

Wyniki badania wskazują również na przewagę objawów pozytywnych w grupie pacjentów bez chorób somatycznych. Ta grupa pacjentów charakteryzuje się młodszym wiekiem oraz krótszym czasem leczenia. Wydaje się jednak, że pomimo istotności statystycznej dotyczącej tej analizy należy podchodzić do niej z rezerwą, gdyż faktem powszechnie znanym jest to, że pacjenci bez choroby somatycznej są młodsi, a objawy pozytywne choroby występują częściej właśnie w tej grupie chorych. Przewaga objawów pozytywnych natomiast może być czynnikiem korzystnym rokowniczo. Objawy pozytywne to grupa objawów bardziej podatna na leczenie przeciwpsychotyczne. Skuteczne w tym przypadku okazują się zarówno leki przeciwpsychotyczne pierwszej, jak i drugiej generacji (Leucht i wsp., 2009).

Obserwowany wraz z wiekiem wzrost ilości punktów uzyskanych w skali objawów ogólnych PANSS u pacjentów bez chorób somatycznych jest interesujący i z pewnością wymaga pogłębienia badań w tym kierunku. Skala objawów ogólnych PANSS zawiera 16 objawów ocenianych w 7-puktowej skali, które mogą w być pośrednio związane zarówno z objawami negatywnymi, jak i pozytywnymi choroby. Dalsze badania powinny dotyczyć poszerzenia wiedzy na temat dominujących objawów w tej grupie pacjentów, co umożliwiłoby wyciągnięcie prawidłowych wniosków. Jednym z objawów zaliczanych do skali ogólnej PANSS jest troska o zdrowie fizyczne. Większa dbałość o zdrowie fizyczne może być w pewnym sensie korzystnym objawem, przyczyniającym się do lepszego stanu fizycznego, a co za tym idzie - zmniejszać ryzyko występowania chorób somatycznych. Z drugiej strony, biorąc pod uwagę fakt, że ocena stanu psychicznego pacjentów miała miejsce wkrótce po przyjęciu do szpitala, niecharakterystyczne objawy, takie jak drażliwość, napięcie, lęk, depresja, znajdujące się w skali ogólnej PANSS, mogą współwystępować u pacjentów z różnymi chorobami somatycznymi, a czynne unikanie kontaktów społecznych i nasilenie objawów negatywnych również narastające $\mathrm{z}$ wiekiem może sprzyjać niewystarczającej diagnostyce, niedostatecznemu rozpoznawaniu i leczeniu chorób współistniejących w tej grupie pacjentów.

Financial support: Grant from Medical University of Lodz from research task no 502-08/5-062-02/502-54-209. / Finansowanie: Grant UM w Łodzi z zadania badawczego nr 502-08/5-062-02/502-54-209.

Conflict of interest non declared. / Nie zgłoszono konfliktu interesów.
Schizofrenia wiąże się z wyższym ryzykiem występowania chorób somatycznych niż w populacji ogólnej oraz krótszą o nawet 20 lat oczekiwaną długością życia (Saha i wsp., 2005; Saha i wsp., 2007; Jaaskelainen i wsp., 2013; Chesney i wsp., 2014). Wśród chorób somatycznych najczęściej opisywane są choroby układu krążenia, w tym choroba niedokrwienna serca oraz cukrzyca typu II, udary mózgu, choroby układu oddechowego (Charlson i wsp., 2018). Przeprowadzona przez Piotrowskiego i wsp. metaanaliza badań dotyczących przyczyn śmierci u pacjentów ze schizofrenią wyraźnie wskazuje na fakt niedostatecznego diagnozowania i leczenia chorób somatycznych w grupie pacjentów ze schizofrenią. Co więcej, podczas gdy w populacji ogólnej oczekiwana długość życia wydłuża się, co wynika z rozwoju medycyny oraz większej dostępności do opieki zdrowotnej, w grupie pacjentów ze schizofrenią ta wartość nie zmienia się, a niekiedy nawet, jak pokazują badania, skraca się (Piotrowski i wsp., 2017).

Poza chorobami somatycznymi do przyczyn wyższych wskaźników śmiertelności przyczyniają się samobójstwa. Nawet 10\% pacjentów ze schizofrenią umiera w wyniku samobójstw (Meltzer i wsp., 2003; Pompili i wsp., 2007; Simms i wsp., 2007). Istotne jest wyodrębnienie czynników ryzyka podjęcia czynu suicydalnego oraz wdrożenie działań mających na celu zminimalizowanie tego ryzyka. Wyniki badania nie wskazują na istotne korelacje żadnych z badanych zmiennych ze zwiększonym ryzykiem samobójstwa.

\section{Wnioski}

Objawy pozytywne choroby występują częściej w grupie pacjentów młodszych, bez współistniejących chorób somatycznych, natomiast wraz z wiekiem pacjenta narastają trudne do leczenia objawy negatywne. Mężczyźni zaczynają chorować na schizofrenię wcześniej. Nie można wyróżnić dominującej grupy objawów psychopatologicznych u kobiet i mężczyzn, u pacjentów z chorobami somatycznymi oraz podejmujących częściej próby samobójcze.

\section{Ograniczenia badania}

Oceniając wyniki tego badania, należy zwrócić uwagę na niewątpliwe ograniczenie, którym są relatywnie niewielkie grupy badanych pacjentów.
The work described in this article has been carried out in accordance with The Code of Ethics of the World Medical Association (Declaration of Helsinki) for experiments involving humans, EU Directive 2010/63/EU for animal experiments, and Uniform Requirements for manuscripts submitted to biomedical journals. / Treści przedstawione w artykule są zgodne z zasadami 
Deklaracji Helsińskiej, dyrektywami EU oraz ujednoliconymi wymaganiami dla czasopism biomedycznych.

Authors' contributions / Wkład autorów: MB-C - conceptual work, data collection and interpretation, literature search / wkład w koncepcję i projekt pracy, zebranie danych i ich interpretacja, zebranie piśmiennictwa; AO - statistical anlysis, preparation of the research results / analiza statystyczna, przygotowanie wyników; PG - conceptual work, acceptance of the final article version / wkład w koncepcję i projekt pracy, akceptacja ostatecznej wersji

\section{References / Piśmiennictwo}

1. Auquier, P., Lancon, C., Rouillon, F., Lader, M. and Holmes, C. Mortality in schizophrenia. Pharmacoepidemiol Drug Saf 2006; 15(12): 873-9.

2. Charlson, F.J., Ferrari, A.J., Santomauro, D.F., Diminic, S., Stockings, E., Scott et al., Global Epidemiology and Burden of Schizophrenia: Findings From the Global Burden of Disease Study 2016. Schizophrenia Bulletin 2018; 44(6): 1195-1203.

3. Chesney, E., Goodwin, G.M. and Fazel, S. Risks of all-cause and suicide mortality in mental disorders: a meta-review. World Psychiatry 2014; 13(2): 153-160.

4. Crump, C., Winkleby, M.A., Sundquist, K. and Sundquist, J. Comorbidities and Mortality in Persons With Schizophrenia: A Swedish National Cohort Study. American Journal of Psychiatry 2013; 170(3): 324-333.

5. Galderisi, S., Bucci, P., Ucok, A. and Peuskens, J. No gender differences in social outcome in patients suffering from schizophrenia. European Psychiatry 2012; 27(6): 406-408.

6. Gogos, A., Ney, L.J., Seymour, N., Van Rheenen, T.E. and Felmingham, K.L. Sex differences in schizophrenia, bipolar disorder, and post-traumatic stress disorder: Are gonadal hormones the link? British Journal of Pharmacology 2019; 176(21): 4119-4135.

7. Jaaskelainen, E., Juola, P., Hirvonen, N., McGrath, J.J., Saha, S., Isohanni, M., Veijola, J. and Miettunen, J. A Systematic Review and Meta-Analysis of Recovery in Schizophrenia. Schizophrenia Bulletin 2013; 39(6): 1296-1306.

8. Kahn, R.S., Sommer, I.E., Murray, R.M., Meyer-Lindenberg, A., Weinberger, D.R., Cannon i wsp., Schizophrenia. Nature Reviews Disease Primers 2015; 1.

9. Kay, S.R., Fiszbein, A. and Opler, L.A. The positive and negative syndrome scale (PANSS) for schizophrenia. Schizophrenia Bulletin 1987; 13(2): 261-276.

10. Kirschner, M., Aleman, A. and Kaiser, S. Secondary negative symptoms - A review of mechanisms, assessment and treatment. Schizophr Res 2017; 186: 29-38.

11. Koster, A., Lindhardt, A., Lajer, M. and Rosenbaum, B. Gender differences in first episode psychosis. Social Psychiatry and Psychiatric Epidemiology 2008; 43(12): 940-946.

12. Leucht, S., Corves, C., Arbter, D., Engel, R.R., Li. i wsp., Secondgeneration versus first-generation antipsychotic drugs for schizophrenia: a meta-analysis. Lancet 2009; 373(9657): 31-41.
13. Lora, A., Kohn, R., Levav, I., McBain, R., Morris, J. and Saxena, S. Service availability and utilization and treatment gap for schizophrenic disorders: a survey in 50 low- and middle-income countries. Bulletin of the World Health Organization 2012; 90(1): 47-54.

14. McGrath, J., Saha, S., Welham, J., El Saadi, O., MacCauley, C. and Chant, D. A systematic review of the incidence of schizophrenia: the distribution of rates and the influence of sex, urbanicity, migrant status and methodology 2004; Bmc Medicine, 2.

15. Meltzer, H.Y., Alphs, L., Green, A.I., Altamura, A.C., Anand, R., Bertoldi, A. et al., Clozapine treatment for suicidality in schizophrenia - International Suicide Prevention Trial (InterSePT). Archives of General Psychiatry 2003; 60(1): 82-91.

16. Ochoa, S., Usall, J., Cobo, J., Labad, X. and Kulkarni, J. Gender differences in schizophrenia and first-episode psychosis: a comprehensive literature review. Schizophr Res Treatment 2012; 916198.

17. Piotrowski, P., Gondek, T.M., Krolicka-Deregowska, A., Misiak, B., Adamowski, T. and Kiejna, A. Causes of mortality in schizophrenia: an updated review of European studies. Psychiatria Danubina 2017; 29(2): 108-120.

18. Pompili, M., Amador, X.F., Girardi, P., Harkavy-Friedman, J., Harrow, M., Kaplan, K. et al., Suicide risk in schizophrenia: learning from the past to change the future. Ann Gen Psychiatry 2007; 6-10.

19. Saha, S., Chant, D. and McGrath, J. A systematic review of mortality in schizophrenia: is the differential mortality gap worsening over time? Arch Gen Psychiatry 2007; 64(10): 1123-31.

20. Saha, S., Chant, D., Welham, J. and McGrath, J. A systematic review of the prevalence of schizophrenia. Plos Medicine 2005; 2(5): 413-433.

21. Simms, J., McCormack, V., Anderson, R. and Mulholland, C. Correlates of self-harm behaviour in acutely ill patients with schizophrenia. Psychology and Psychotherapy-Theory Research and Practice 2007; 80: 39-49.

22. Sun, J., Walker, A.J., Dean, B., van den Buuse, M. and Gogos, A. Progesterone: The neglected hormone in schizophrenia? A focus on progesterone-dopamine interactions. Psychoneuroendocrinology 2016; 74: 126-140.

23. Szulc, A., Dudek, D., Samochowiec, J., Wojnar, M., Heitzman, J. and Gałecki, P. Recommendations for the treatment of schizophrenia with negative symptoms. Standards of pharmacotherapy by the Polish Psychiatric Association (Polskie Towarzystwo Psychiatryczne), part 2. Psychiatr Pol 2019; 53(3): 525-540.

24. Szymanski, S., Lieberman, J.A., Alvir, J.M., Mayerhoff, D., Loebel, A., Geisler, S. i wsp., Gender differences in onset of illness, treatment response, course, and biologic indexes in first-episode schizophrenic patients. American Journal of Psychiatry 1995; 152(5): 698-703.

25. Zhang, X.Y., Chen, D.C., Xiu, M.H., Yang, F.D., Haile, C.N., Kosten, T.A. i wsp., Gender Differences in Never-Medicated First-Episode Schizophrenia and Medicated Chronic Schizophrenia Patients. Journal of Clinical Psychiatry 2012; 73(7): 1025-1033. 
